In Focus

\title{
Sodium tungstate dihydrate
}

Duarte, T. A. G.

Rev. Virtual Quim., 2013, 5 (2), 318-325. Online publication: 22 April 2013

http://www.uff.br/rvq

\section{Tungstato de sódio di-hidratado}

Resumo: $O$ tungstato de sódio di-hidratado é um reagente disponível comercialmente sob a forma de um sólido cristalino branco e é geralmente usado na síntese de compostos inorgânicos, nomeadamente na síntese de polioxometalatos. O tungstato de sódio di-hidratado também pode ser usado como catalisador ou como precursor de catalisador em várias reações orgânicas. Este manuscrito apresenta uma revisão das aplicações do tungstato de sódio di-hidratado em reações orgânicas, nomeadamente epoxidação, clivagem de ligações duplas, oxidação de álcoois, aminas, iminas ou compostos orgânicos de enxofre, halogenação de compostos aromáticos, síntese de brometos $\beta$-arilvinílicos e síntese de 1 - $H$-tetrazóis.

Palavras-chave: Tungstato de sódio; catalisador; química orgânica.

\begin{abstract}
s
Sodium tungstate dihydrate is a commercially available reagent, in the form of a crystalline white solid, which is usually used in the synthesis of inorganic compounds, namely in polyoxometalates synthesis. Sodium tungstate dihydrate can also be used as catalyst or as catalyst precursor in several organic reactions, namely epoxidation, cleavage of double bonds, oxidation of alcohols, amines, imines, and organosulfur compounds, halogenation of aromatic compounds, synthesis of $\beta$-arylvinyl bromides, and synthesis of 1 - $H$-tetrazoles.
\end{abstract}

Keywords: Sodium tungstate; catalyst; organic chemistry.

\footnotetext{
* University of Aveiro, Department of Chemistry and QOPNA, 3810-193 Aveiro, Portugal.

Ma39903@ua.pt

DOI: $10.5935 / 1984-6835.20130030$
} 


\section{Sodium tungstate dihydrate}

\section{Tiago André G. Duarte}

University of Aveiro, Department of Chemistry and QOPNA, 3810-193 Aveiro, Portugal.

*a39903@ua.pt

Received 15 February 2013. Accept 8 April 2013

Tiago Duarte is a post-graduate student at the University of Aveiro, Portugal. Tiago has received his Master degree in Chemistry at July 2012 from the University of Aveiro, under the supervision of Dr. Isabel Santos Vieira and Dr. Mário Simões, both from the laboratory of Professor José Cavaleiro.

Tiago's research interests focus mainly on polyoxometalates synthesis and characterization and their use as catalysts. Tiago is now preparing his research project in order to start his PhD studies at the same University.

\section{Introduction}

Sodium tungstate dihydrate is a commercially available reagent which exists in the form of a crystalline white solid. Sodium tungstate dihydrate is usually used in the synthesis of inorganic compounds, namely in polyoxometalates synthesis. It can also be used in organic chemistry as a green catalyst or catalyst precursor, since sodium tungstate dihydrate is able to catalyze the oxidation of several substrates in the presence of hydrogen peroxide, generating only water as the by-product (Scheme 1). On the other hand, the conjugation of this reagent with other inorganic reagents used in polyoxometalates synthesis ${ }^{1}$ permits the formation of several complexes, mainly peroxocomplexes, ${ }^{2}$ which can catalyze some oxidation reactions by themselves.

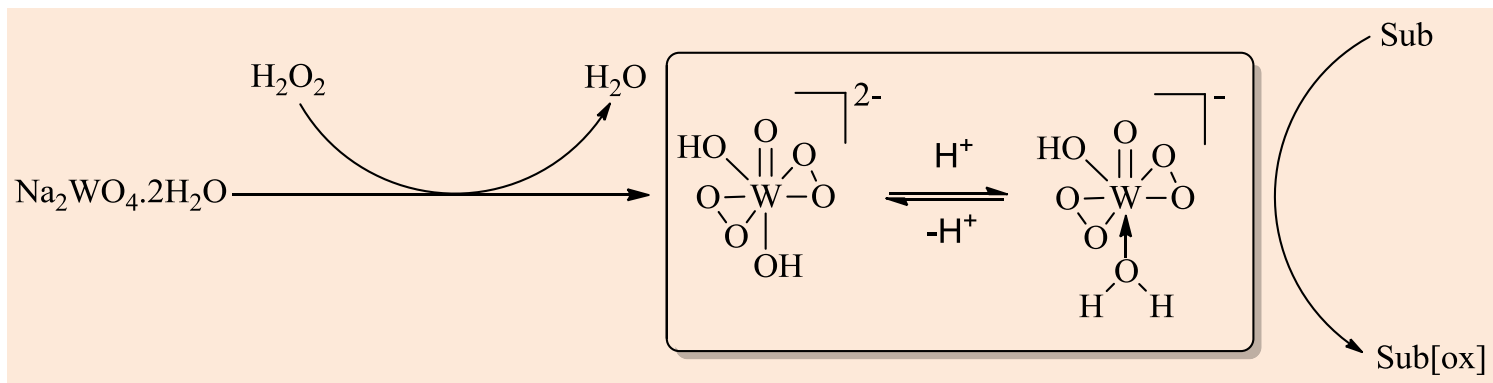

Scheme 1. General oxidation reaction pathway using sodium tungstate dihydrate as a catalyst precursor and hydrogen peroxide as oxidant 


\section{Applications}

Sodium tungstate dihydrate can be used as catalyst or as catalyst precursor in several organic reactions, namely:

\section{a) Epoxidation}

The sodium tungstate catalyzed epoxidation of $\alpha, \beta$-unsaturated acids by hydrogen peroxide in water has been developed by Payne in 1959, ${ }^{3,4}$ and revisited by Sharpless in 1985, also in water. ${ }^{4,5}$ According to Sheldon, the epoxidation of allyl alcohol to glycidol using hydrogen peroxide and sodium tungstate was applied industrially as an alternative to the traditional route via epichlorohydrin. ${ }^{6}$ The epoxidation procedure developed by Venturello and co-workers, ${ }^{7}$ using a $\mathrm{Na}_{2} \mathrm{WO}_{4} \cdot 2 \mathrm{H}_{2} \mathrm{O} / \mathrm{H}_{3} \mathrm{PO}_{4}$ /quaternary ammonium chloride/aqueous $8 \%$ hydrogen peroxide system presents some drawbacks, since requires an excess of olefinic substrates and uses 1,2-dichloroethane, a toxic and carcinogenic chlorinated hydrocarbon solvent. In contrast, Noyori and co-workers reported a clean, halide-free, biphasic epoxidation method with $30 \%$ hydrogen peroxide in the presence of sodium tungstate dihydrate, (aminomethyl)phosphonic acid, and a phase transfer catalyst (PTC) such as $\mathrm{Q}^{+} \mathrm{HSO}_{4}^{-}\left(\mathrm{Q}^{+}=\right.$ $\left.\mathrm{CH}_{3}\left(n-\mathrm{C}_{8} \mathrm{H}_{17}\right)_{3} \mathrm{~N}^{+}\right)$to epoxidize olefins such as cyclooctene (98\% yield) or 1-dodecene $(87 \%$ yield). Functionalized olefins containing an ester, ether, alcohol, or $\alpha, \beta$-enone linkage in the same molecule can also be epoxidized by this procedure. ${ }^{8-10}$

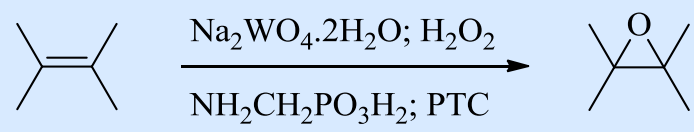

The epoxidation of 1,4-bis(allyloxy)butane in the presence of sodium tungstate dihydrate and orthophosphoric acid gives 1-allyloxy-4-glycidoloxybutane and 1,4-bis(glycidoloxy)butane under phase transfer conditions, using $30 \%$ hydrogen peroxide as oxidant. ${ }^{11}$ Methyltrioctylammonium chloride (Aliquat 336) was used as phase transfer catalyst (PTC). Sodium tungstate dihydrate can be used also as catalyst in the epoxidation of terpenes, such as limonene, geraniol, nerol or 3-carene, using a phosphate buffer solution of $\mathrm{H}_{3} \mathrm{PO}_{4} / \mathrm{NaH}_{2} \mathrm{PO}_{4}{ }^{12}$
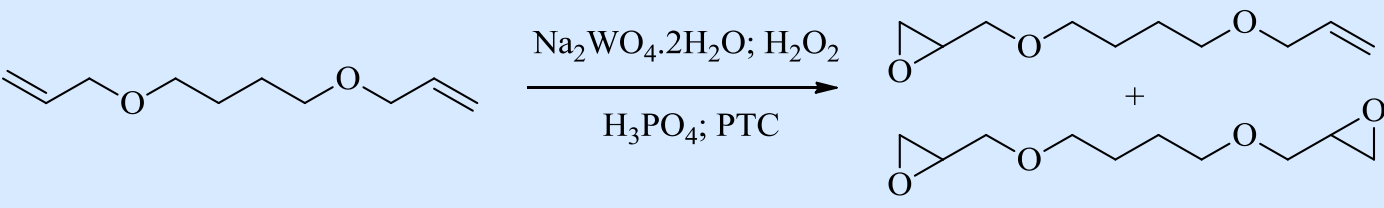

\section{b) Cleavage of double bonds (to carboxylic acids, aldehydes or ketones)}

A convenient and efficient method for converting cyclohexene into adipic acid has been reported. This protocol represents a new and green viewpoint for the synthesis of adipic acid, since this approach replaces usual hazardous oxidizing agents, such as nitric acid, for an environmentally benign one, aqueous hydrogen peroxide. When a mixture of cyclohexene, hydrogen peroxide, sodium tungstate dihydrate and $\left[\mathrm{CH}_{3}\left(n-\mathrm{C}_{8} \mathrm{H}_{17}\right){ }_{3} \mathrm{~N}\right] \mathrm{HSO}_{4}$ as PTC is kept at 75 
o $\mathrm{C}$ to 90 o $\mathrm{C}$ for 8 hours, adipic acid is obtained in $93 \%$ yield. Adipic acid is an important chemical, whose production is necessary for the manufacture of nylon-6,6. This procedure is equally applicable to the oxidation of substituted cyclohexenes. Moreover, the oxidation cyclopentene produced crystalline glutaric acid in $90 \%$ yield. ${ }^{8,13}$

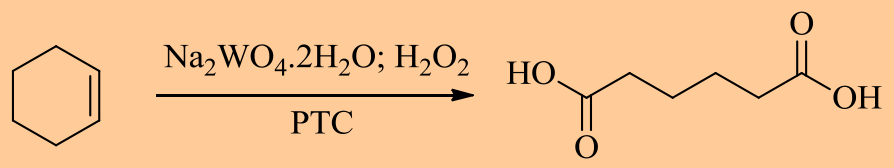

Recently, a catalytic system based on $\mathrm{Na}_{2} \mathrm{WO}_{4} \cdot 2 \mathrm{H}_{2} \mathrm{O} / \mathrm{CH}_{3} \mathrm{CO}_{2} \mathrm{H} / \mathrm{H}_{2} \mathrm{O}_{2}$ was developed as an effective method to oxidize natural rubber (with a large number of carbon-carbon double bonds in its structure) into the corresponding epoxy derivatives. This catalytic system possesses much higher epoxidation efficiency than the traditional $\mathrm{CH}_{3} \mathrm{CO}_{2} \mathrm{H} / \mathrm{H}_{2} \mathrm{O}_{2}$ system. The proposed method also induces further oxidation of the epoxides into the corresponding ketones and aldehydes, resulting from C-C cleavage. ${ }^{14}$

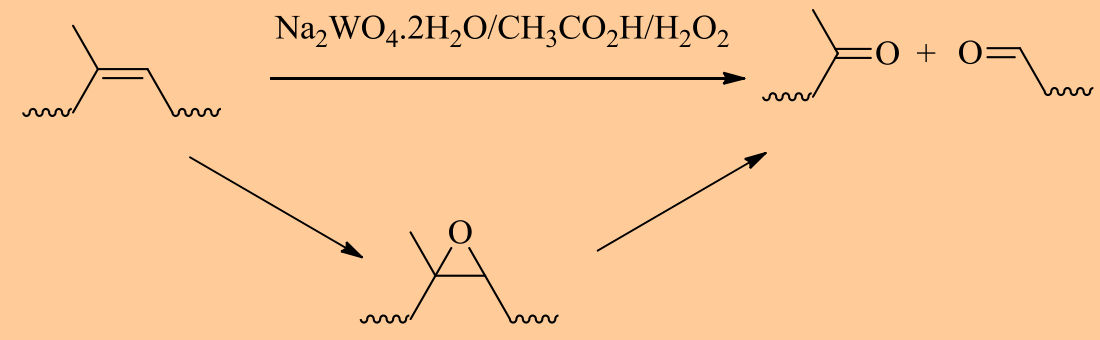

\section{c) Oxidation of alcohols}

Secondary alcohols can be converted into the corresponding ketones (83-96\% yield) under biphasic conditions (organic/aqueous) using $30 \%$ hydrogen peroxide in the presence of sodium tungstate dihydrate as catalyst and an appropriate PTC such as $\left[\mathrm{CH}_{3}-\left(n-\mathrm{C}_{8} \mathrm{H}_{17}\right)_{3} \mathrm{~N}\right] \mathrm{HSO} \mathrm{O}_{4}$. Noyori and co-workers studied several cases with alkyl or aryl groups, namely 2-octanol or 1phenylethanol, under solvent-free conditions or using toluene as solvent. ${ }^{8,15}$

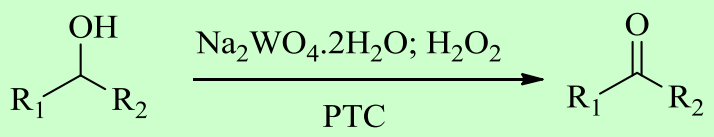

The same approach can be used for primary alcohols. However, in the case of primary benzylic alcohols, the amount of hydrogen peroxide used affects the final product. Noyori and co-workers reported that when a small amount of hydrogen peroxide ( $<1.5$ molar amount) is used to oxidize primary benzylic alcohols, the corresponding aldehydes can be obtained; if a higher amount of hydrogen peroxide (2.5 - 5 molar amount) is added, the corresponding benzoic acids can be produced. The efficiency is highly dependent on the electronic properties of substituents. ${ }^{8,15}$ 
Duarte, T. A. G.

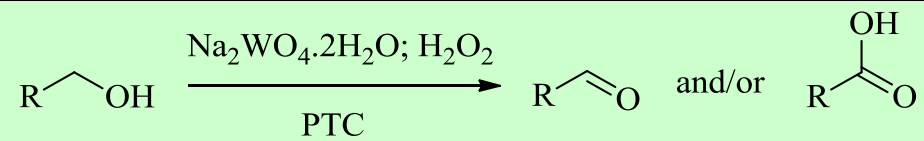

d) Oxidation of amines (primary amines to hydroxylamines and nitro derivates and secondary amines to nitrones)

Sodium tungstate dihydrate catalyzes the oxidation of primary amines to the corresponding $\mathrm{N}$-monoalkylhydroxylamines, important biologically active compounds, in the presence of UHP (urea-hydrogen peroxide adduct). This method can be applied for several primary amines, including chiral benzylic amines, $\alpha$-1,2-hydroxylamines and $\alpha$-amino esters, yields ranging from $65 \%$ to $80 \%{ }^{16}$

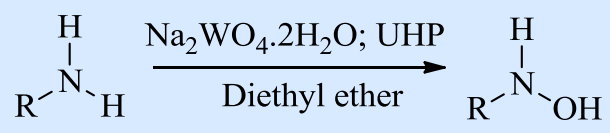

Very recently, Leonard and co-workers reported that sodium tungstate dihydrate promotes the oxidation of diamine (1) using $90 \%$ hydrogen peroxide in sulfuric acid. Since product (2) is very unstable, the authors propose that these reactions should be done with extreme caution, by knowledgeable researchers. ${ }^{17}$<smiles>Nc1nonc1C1=NOC(c2nonc2N)=NO1</smiles>

The sodium tungstate dihydrate catalyzed oxidation of secondary amines with hydrogen peroxide gives the corresponding nitrones in methanol or water, at room temperature. Acyclic and cyclic nitrones can be obtained from secondary amines in a single step in good to excellent yields. ${ }^{18}$

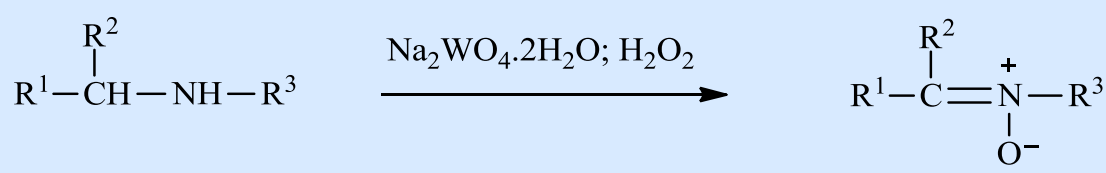

According to Varlamov and co-workers, the synthesis of cyclic nitrones (4) can be carried out using $\mathrm{H}_{2} \mathrm{O}_{2}$ and a catalytic amount of sodium tungstate dihydrate, at room temperature, with moderate to high yields, as exemplified for 2-benzazepines (3). ${ }^{19}$ 
<smiles>[R]c1ccc2c(c1)C([R])NC1(CCCC1)CC2([R])C</smiles>

(3)

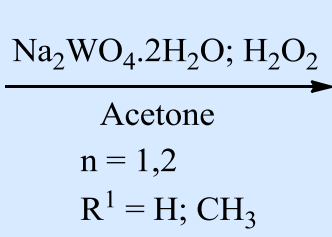

$\mathrm{R}^{2}=\mathrm{H} ; \mathrm{CH}_{3}$ $\mathrm{R}^{3}=\mathrm{H} ; \mathrm{NO}_{2}$

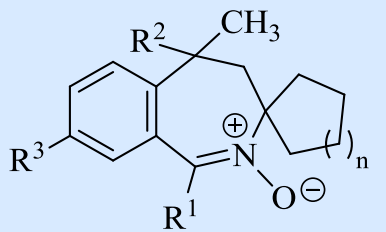

(4)

\section{e) Oxidation of imines}

The oxidation of $\mathrm{N}$-alkyl imines with $30 \%$ hydrogen peroxide, in the presence of sodium tungstate dihydrate, led to the highly selective synthesis of oxaziridines in acetonitrile under mild conditions. ${ }^{20}$

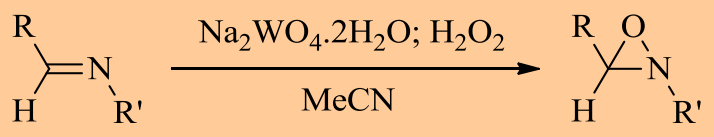

\section{f) Oxidation of organosulfur compounds}

The oxidation of organosulfur compounds is the most straightforward method for the preparation of sulfoxides and sulfones, important as commodity chemicals or pharmaceuticals. Noyori and co-workers reported an oxidative process using sodium tungstate dihydrate as catalyst, $30 \%$ aqueous $\mathrm{H}_{2} \mathrm{O}_{2}$ as oxidant, and $\mathrm{Q}^{+} \mathrm{HSO}_{4}{ }^{-}$as PTC, besides phenylphosphonic acid as a promoter of the biphasic oxidation, which converts several aromatic and aliphatic organosulfur compounds into the corresponding sulfoxides and sulfones without organic solvents. With this method diphenyl sulfide is converted into diphenyl sulfone with $96 \%$ yield. The authors studied others substrates, the aliphatic sulfides being more reactive than the aromatic counterparts. Moreover, the substrates with allyl groups or with primary or secondary alcohols are oxidized to the corresponding sulfones, the allylic and the alcohol groups being unaffected. ${ }^{8,21}$

$$
\mathrm{R}_{1}^{-}{ }^{-\mathrm{S}_{-}} \mathrm{R}_{2} \stackrel{\mathrm{Na}_{2} \mathrm{WO}_{4} \cdot 2 \mathrm{H}_{2} \mathrm{O} ; \mathrm{H}_{2} \mathrm{O}_{2}}{\mathrm{C}_{6} \mathrm{H}_{5} \mathrm{PO}_{3} \mathrm{H}_{2} ; \mathrm{PTC}} \mathrm{R}_{1}^{-} \text {' }^{\prime \prime \prime}{ }_{\mathrm{R}_{2}}^{\prime \prime}
$$

\section{g) Halogenation of aromatic compounds}

The regioselective halogenation of some aromatic substrates using $\mathrm{KCl}$ or $\mathrm{KBr}$ in the presence of sodium perborate (SPB) as oxidant and sodium tungstate dihydrate as catalyst, is an environmentally friendly catalytic halogenation procedure, which can provide good yields (up to $92 \%$ ) under mild conditions. ${ }^{22}$ 


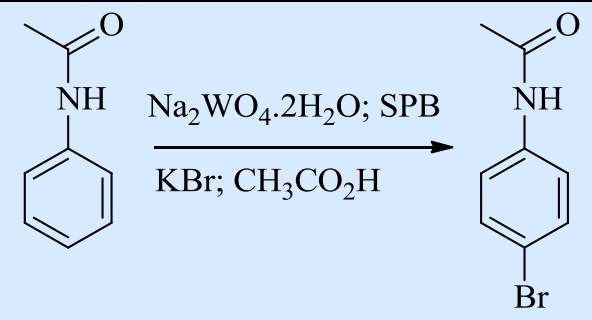

\section{h) Synthesis of $\beta$-arylvinyl bromides}

Roy and Bhar reported the synthesis of several $\beta$-arylvinyl bromides under environmentally friendly conditions (using water as solvent) through a bromodecarboxylation reaction of cinnamic acids with potassium bromide, using $30 \%$ hydrogen peroxide as oxidant and sodium tungstate dihydrate as catalyst, with moderate to good yields. ${ }^{23}$

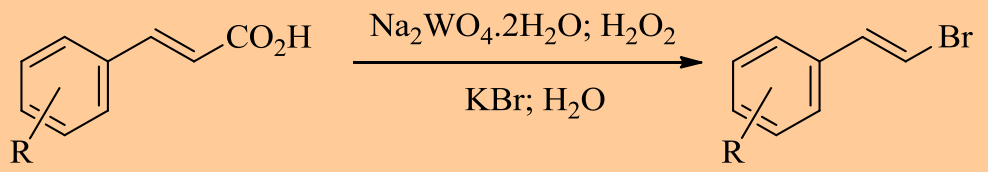

\section{i) Synthesis of 5-substituted 1-H-tetrazoles}

The $[2+3]$ cycloaddition reaction between nitriles and sodium azide, catalyzed by several tungstates, produced the corresponding 5 -substituted $1-H$-tetrazoles. Sodium tungstate dihydrate was used only for benzonitrile and $36 \%$ yield was obtained. ${ }^{24}$

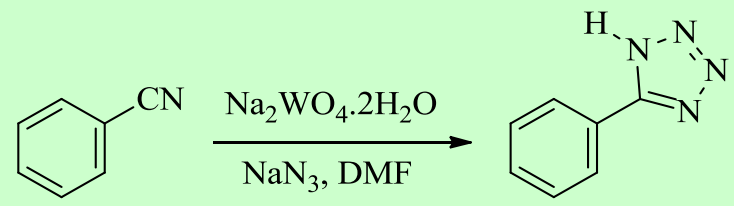

\section{References}

${ }^{1}$ a) Tourné, C. M.; Tourné, G. F.; Malik, S. A.; Weakley, T. J. R. J. Inorg. Nucl. Chem. 1970, 32, 3875; [CrossRef] b) Tourné, C. M.; Tourné, G. F. Bull. Soc. Chim. Fr. 1969, 4, 1124; c) Weakley, T. J. R. J. Chem. Soc., Dalton Trans. 1973, 341. [CrossRef]

${ }^{2}$ a) Santos, I. C. M. S.; Paz, F. A. A.; Simões, M. M. Q.; Neves, M. G. P. M. S.; Cavaleiro, J. A. S.; Klinowski, J.; Cavaleiro, A. M. V. Appl. Catal. A: General 2008, 351, 166; [CrossRef] b) Santos, I. C. M. S.; Balula, S. S.; Simões, M. M. Q.; Cunha-Silva, L.; Neves, M. G. P. M. S.; de Castro, B.; Cavaleiro, A. M. V.; Cavaleiro, J. A. S. Catal. Today 2013, 203, 87. [CrossRef]

${ }^{3}$ Payne, G. B.; Williams P. H. J. Org. Chem. 1959, 24, 54. [CrossRef]

${ }^{4}$ Jorgensen, K. A. Chem. Rev. 1989, 89, 431. [CrossRef]

${ }^{5}$ Kirshenbaum, K. S.; Sharpless, K. B. J. Org. Chem. 1985, 50, 1979. [CrossRef]

${ }^{6}$ Sheldon, R. A.; Kochi, J. K.; Metal-Catalyzed Oxidations of Organic Compounds, Academic Press: New York, 1981, chapter 9.

${ }^{7}$ Venturello, C.; Alneri, E.; Ricci, M. J. Org. Chem. 1983, 48, 3831. [CrossRef] 
${ }^{8}$ Noyori, R.; Aoki, M.; Sato, K. Chem. Commun. 2003, 1977. [CrossRef]

${ }^{9}$ Sato, K.; Aoki, M.; Ogawa, M.; Hashimoto, T.; Panyella, D.; Noyori, R. Bull. Chem. Soc. Jpn. 1997, 70, 905. [CrossRef]

${ }^{10}$ Sato, K.; Aoki, M.; Ogawa, M.; Hashimoto, T.; Noyori, R. J. Org. Chem. 1996, 61, 8310. [CrossRef]

${ }^{11}$ Kaczmarcyk, E.; Milchert, E.; Janus, E. Chem. Eng. Technol. 2009, 32, 881. [CrossRef]

${ }^{12}$ Grigoropoulou, G.; Clark, J. H. Tetrahedron Lett. 2006, 47, 4461. [CrossRef]

${ }^{13}$ Sato, K.; Aoki, M.; Noyori, R. Science 1998, 281, 1646. [CrossRef]

${ }^{14}$ Zhang, J.; Zhou, Q.; Jiang, X. H.; Du, A. K.; Zhao, T.; van Kasteren, J.; Wang, Y. Z. Polym. Degrad. Stabil. 2010, 95, 1077. [CrossRef]

${ }^{15}$ Sato, K.; Aoki, M.; Takagi, J.; Noyori, R. J. Am. Chem. Soc. 1997, 119, 12386. [CrossRef]

${ }^{16}$ Heydari, A.; Aslanzadeh, S. Adv. Synth. Catal. 2005, 347, 1223. [CrossRef]
${ }^{17}$ Leonard, P. W.; Pollard, C. J.; Chavez, D. E.; Rice, B. M.; Parrish, D. A. Synlett 2011, 2097. [CrossRef]

${ }^{18}$ Murahashi, S.-I.; Mitsui, H.; Shiota, T.; Tsuda, T.; Watanabe, S. J. Org. Chem. 1990, 55, 1736. [CrossRef]

${ }^{19}$ Varlamov, A.; Kouznetsov, V.; Zubkov, F.; Chernyshev, A.; Alexandrov, G.; Palma, A.; Vargas, L.; Salas, S. Synthesis 2001, 849. [CrossRef]

${ }^{20}$ Shailaja, M.; Manjula, A.; Rao, B. V. Synlett 2005, 1176. [CrossRef]

${ }^{21}$ Sato, K.; Hyodo, M.; Aoki, M.; Zheng, X. Q.; Noyori, R. Tetrahedron 2001, 57, 2469. [CrossRef]

22 Bandgar, B. P.; Nigal, N. J. Synth. Commun. 1998, 28, 3225. [CrossRef]

${ }^{23}$ Roy, S.; Bhar, S. Green Chem. Lett. Rev. 2010, 3, 341. [CrossRef]

${ }^{24} \mathrm{He}$, J.; Li, B.; Chen, F.; Xu, Z.; Yin, G. J. Mol. Catal. A: Chem. 2009, 304, 135. [CrossRef] 